NBER WORKING PAPER SERIES

\title{
RACE, INCOME AND COLLEGE IN 25 YEARS: THE CONTINUING LEGACY OF SEGREGATION AND DISCRIMINATION
}

\author{
Alan Krueger \\ Jesse Rothstein \\ Sarah Turner \\ Working Paper 11445 \\ http://www.nber.org/papers/w11445

\section{NATIONAL BUREAU OF ECONOMIC RESEARCH \\ 1050 Massachusetts Avenue \\ Cambridge, MA 02138} \\ June 2005
}

We would like to thank Bill Bowen for suggesting this research agenda over dinner, Martin Kurzweil and Nirupama S. Rao for providing tabulations from the Mellon Expanded College \& Beyond database. The UCLA Center on Education Policy and Evaluation, the Russell Sage Foundation, and the Princeton Industrial Relations Section provided generous research support. We are grateful to Gary Solon and Martin Kurzweil for excellent comments on an earlier version of this draft. E-mail correspondence can be addressed to Alan Kreuger (akreuger@princeton.edu), Jesse Rothstein (jrothst@princeton.edu), or Sarah Turner (sturner@virginia.edu). The views expressed herein are those of the author(s) and do not necessarily reflect the views of the National Bureau of Economic Research.

(C2005 by Alan Krueger, Jesse Rothstein, and Sarah Turner. All rights reserved. Short sections of text, not to exceed two paragraphs, may be quoted without explicit permission provided that full credit, including () notice, is given to the source. 
Race, Income, and College in 25 Years: The Continuing Legacy of Segregation and Discrimination Alan Krueger, Jesse Rothstein, and Sarah Turner NBER Working Paper No. 11445

June 2005

JEL No. I2, J15, J7

\begin{abstract}
$\underline{\text { ABSTRACT }}$
The rate at which racial gaps in pre-collegiate academic achievement can plausibly be expected to erode is a matter of great interest and much uncertainty. In her opinion in Grutter v. Bollinger, Supreme Court Justice O'Connor took a firm stand: "We expect that 25 years from now, the use of racial preferences will no longer be necessary ..." We evaluate the plausibility of Justice O'Connor's forecast, by projecting the racial composition and SAT distribution of the elite college applicant pool 25 years from now. We focus on two important margins: First, changes in the black-white relative distribution of income, and second, narrowing of the test score gap between black and white students within family income groups. Other things equal, progress on each margin can be expected to reduce the racial gap in qualifications among students pursuing admission to the most selective colleges. Under plausible assumptions, however, projected economic progress will not yield nearly as much racial diversity as is currently obtained with race-sensitive admissions. Simulations that assume additional increases in black students' test scores, beyond those deriving from changes in family income, yield more optimistic estimates. In this scenario, race-blind rules approach the black representation among admitted students seen today at moderately selective institutions, but continue to fall short at the most selective schools. Maintaining a critical mass of African American students at the most selective institutions would require policies at the elementary and secondary levels or changes in parenting practices that deliver unprecedented success in narrowing the test score gap in the next quarter century.
\end{abstract}

Alan Krueger

Woodrow Wilson School

Princeton University

Princeton, NJ 08544

and NBER

akrueger@princeton.edu
Jesse Rothstein

Industrial Relations Section

A-17-J1 Firestone Library

Princeton University

Princeton, NJ 08544

and NBER

jrothst@princeton.edu
Sarah Turner

University of Virginia

Ruffner Hall, Room 294B

405 Emmet Street

Charlottesville, VA 22903-2495

and NBER

sturner@virginia.edu 


\section{Race, Income and College in 25 Years: The Continuing Legacy of Segregation and Discrimination}

Even in the absence of continuing bias, the legacies of de jure segregation and racial discrimination in the United States would contribute to lingering gaps in income and educational attainment between blacks and whites. These gaps create substantial challenges for public policy in many arenas. In higher education, much of the debate focuses on access to highly selective, elite colleges, which are perceived to be important stepping stones to professional and leadership positions. Because there are comparatively few black high school graduates with exceptional academic records, the most selective colleges and universities would not admit many black students using purely academic admissions rules. Thus, many colleges and universities attempt to offset the gaps in the credentials of black and white applicants by giving an advantage in admission to black students over whites with similar academic records.

In the 50 years since the Supreme Court ruled in its landmark 1954 Brown vs. Board of Education decision that "separate educational facilities are inherently unequal" and, a year later, that public schools should be desegregated "with all deliberate speed," realized changes in educational and economic outcomes have been slower and more complicated than might have been hoped. The rate at which racial gaps in pre-collegiate academic achievement can plausibly be expected to erode going forward is thus a matter of some uncertainty. In her opinion in the Grutter v. Bollinger case, which held some forms of affirmative action in college admissions to be constitutional, Justice O’Connor takes a firm stand on this question: "We expect that 25 years from now, the use of racial 
preferences will no longer be necessary to further the interest approved today.” Our goal in this paper is to evaluate the plausibility of Justice O'Connor's forecast.

We attempt to project the elite college applicant pool 25 years from now, under assumptions - which we believe are somewhat optimistic -- about the rate at which existing racial gaps in economic circumstances and pre-collegiate educational achievement will likely close in the future. Our analysis focuses on two important margins: First, changes in the black-white relative distribution of income, and second, narrowing of the test score gap between black and white students with similar family incomes. Other things being equal, progress on each margin can be expected to reduce the racial gap in qualifications among students pursuing admission to the most selective colleges. We use existing estimates of the speed of regression toward the mean income across generations to project the future black-white family income gap, and past trends in test score convergence between black and white students to project the conditional-onincome test score gap. Combining the two projections with a unique national data set on SAT test takers, we obtain a predicted future distribution of black test scores relative to those of whites.

After projecting the pool of likely applicants, we simulate the effects of alternative admissions policies -- including the current race-conscious system, raceneutral SAT-based admissions, and class-based affirmative action -- on the racial composition of admitted students. We focus exclusively on black and white students because immigration and immigrant assimilation make projections of Hispanic and Asian applicant pools substantially more difficult to produce and interpret and because the representation of African Americans in colleges is, in light of the United States' distinct 
historical legacy of racial policies, of unique interest. We also restrict our analysis to selective institutions, as race-conscious admissions policies are only relevant where admissions are competitive. We can thus say little about aggregate differences in collegiate attainment, which primarily reflect differences between black and white high school students in enrollment and attainment at open access institutions that lack selective admissions policies.

The legacy of racial inequality in academic and economic opportunity forms the background of the admissions debate and of this analysis. The first section of this paper traces the history of black-white inequality of opportunity and of the racial gap in outcomes at the elementary and secondary levels. The second section turns to racial inequality in higher education opportunities and outcomes and to the role of policies such as affirmative action. In the third section, we address the empirical question of the expected relative representation of black and white students among the pool of students likely to be admitted to the most selective colleges and universities.

Although our forecasted distribution of applicants to selective colleges is necessarily speculative, we hope that the bases for our speculation are at least clear. Furthermore, our key variables are connected to the legacy of past discrimination. If nothing else, our approach provides a starting point for evaluating the plausibility of Justice O'Connor's forecast and for considering the impact of various influences on the credentials of college applicants. In particular, our forecasted distribution is obviously sensitive to policy changes in the coming decades. Changes in class size, in school effectiveness, and in income inequality would all have important effects on black representation among elite college applicants, admissions, and matriculants. We do not 
take these into account, but rather see our results as a baseline expectation in the absence of dramatic policy shifts. We focus on admission rates, the outcome most directly connected to legal rules, and stop short of attempting to predict matriculation.

\section{Section 1. Racial inequality in education and achievement}

The decision in Brown v. Board of Education provided a statutory end to racial segregation in public schooling, but it did not eliminate the functional segregation of public schools. Boozer, Krueger, and Wolkon (1992) examine the extent of segregation experienced by students attending high school between the 1920s and the 1970s. They find that there was no noticeable decline during the decade after the Brown decision in the overwhelming proportion of black students who attended all-black schools. Only after the Civil Rights Act of 1964 did the share of black Americans attending segregated schools begin a sharp decline.

Arguably, one legacy of the history of segregation is the substantial gap in measured academic performance between black and white children. There was an enormous gap in school funding throughout most of the first half of the $20^{\text {th }}$ Century. Approximately $80 \%$ of blacks grew up in one of the 18 legally segregated states plus the District of Columbia. In 1915, these 18 jurisdictions had an average pupil-teacher ratio of 61 in black schools and 38 in white schools. The racial gap in measured school inputs had narrowed substantially by the time of the Brown decision. In the 1953-54 school year the average pupil-teacher ratio was 32 in black schools and 28 in white schools. As documented by Horace Mann Bond (1934), in areas where blacks were relatively more numerous a greater share of school resources was diverted from the black schools to 
white schools. Bond (pp. 244-245) wrote emphatically: "Negro schools are financed from the fragments which fall from the budget made up for white children. Where there are many Negro children, the available funds are given principally to the small white minority."

It is hard to imagine that such large differences in school resources, as well as segregation itself, did not affect student achievement (see Krueger and Whitmore, 2002, and Crain and Mahard, 1983). It is also likely that such learning deficits would persist, at least in part, from one generation to the next.

Representative test score data are only available recently. In 1970, the average black student scored more than one standard deviation below the average white student on the first National Assessment of Education Progress (NAEP) assessment (see Figure 1). Though the gap has narrowed significantly since then, progress has been slow and episodic, with essentially no further progress since 1990 . Convergence at the $90^{\text {th }}$ percentile of the black and white distributions, perhaps more relevant for admission to selective colleges, is not noticeably different from convergence at the mean. After 30 years of de jure integration, the gap stands at about three quarters of a standard deviation in reading, and even higher in math.

An obvious partial explanation for the persistence of gaps in academic performance is the continuing gap in family economic resources between black and white children. Parental income is unquestionably an important correlate of student test-scores, though the exact channel through which it influences performance is unclear. ${ }^{1}$ It thus

\footnotetext{
${ }^{1}$ Two possibilities are that income is related to parental education levels, which may have a direct effect on human capital transmission in the home, and that higher incomes permit access to better schools and to complements to in-school learning such as books, field trips and extracurricular activities.
} 
seems likely that the black-white test score gap would be substantially narrower if the black-white family income gap could be reduced.

The family income gap is clearly related to the differential labor market experience of black and white workers. Blacks earn substantially less, on average, than do whites, though the gap has slowly narrowed as black schooling has improved and discrimination has declined. In 1960, the average black male earned 40\% less than the average white male and in 1980 the average black male earned 25\% less. Card and Krueger’s $(1992,1993)$ estimates imply that the improvement in the relative quality of education for succeeding generations of black workers accounted for roughly $20 \%$ of the narrowing of the black-white earnings gap over this period. A reduction in discrimination in conjunction with normal market forces likely accounts for the bulk of the remainder (see, e.g., Freeman, 1973; Donohue and Heckman, 1991; and Card and Krueger, 1993).

The improved labor market performance for adult black workers has been slow to translate to improved economic circumstances for black children, as the deterioration in black family structures has partially offset increases in individual earnings. While the likelihood of living in a two-parent family has declined for all children, the change has been larger for black children. In 2002, 35\% of black children resided in families with two parents, down from 59\% of black children in 1968; for white children, $74 \%$ resided in families with two parents in 2002, down from $89 \%$ in $1968 .{ }^{2}$ Data from the Current Population Survey show that the gap in total family income between black and white children has hardly moved in three decades: The ratio of the median income for black

\footnotetext{
${ }^{2}$ http://www.census.gov/population/socdemo/hh-fam/tabCH-3.xls, Tables CH-2 and CH3
} 
families with one child to the median income for similar white families was 0.63 in 1967 and 0.62 in $2001 .^{3}$

Still, differences in family incomes are not the only factor behind the persistence of the black-white test score gap, as there remains a sizable racial gap among families with similar incomes. Focusing largely on young children, Phillips and coauthors find that only about two-thirds of the black-white gap in scores is explained by even a rich set of family background measures (Phillips et. al., 1998), leaving one third unaccounted for. The causal process generating the black-white gap within income groups is difficult to pin down. One explanation that we consider below is that it could relate to continued school segregation, and to relatively low quality of schools attended by black students.

\section{Section 2. Black and White Collegiate Access and Outcomes: From Segregation to Affirmative Action}

\section{A. Collegiate Opportunities before Brown}

With two thirds of the black population living in the South at the conclusion of World War II, most potential students faced explicitly segregated choices in higher education, with many of these "separate" alternatives small and underfunded relative to institutions for whites. Outside the South, opportunities were somewhat better, and regional differences in collegiate attainment grew further when non-South blacks used G.I. Bill benefits at higher rates than did blacks in the South. ${ }^{4}$

\footnotetext{
${ }^{3}$ http://www.census.gov/hhes/income/histinc/incfamdet.html, Tables F9A and F9B

${ }^{4}$ The G.I. Bill (formally, the Serviceman's Readjustment Act, Public Law 346, 1944), was notably race-neutral in its statutory terms. Educational benefits were exceedingly generous and extended from a minimum of one year to four years, depending on length of service and age. Blacks in the South may have faced difficulties, however, in finding colleges that were open to them where they could use their G.I. Bill benefits, potentially hindering take-up.
} 
Early civil rights litigation challenged the status quo in which black and white students faced demonstrably different collegiate opportunities. A 1938 Supreme Court ruling (Missouri ex rel. Gaines v. Canada, 305 U.S. 337) found that a Missouri policy which barred blacks from the state law school and, instead, provided tuition money to attend a school out-of-state was in violation of the Equal Protection Clause of the Fourteenth Amendment. In 1949, the Supreme Court ruled in Sweatt v. Painter that the establishment of a separate law school for blacks would not satisfy the Fourteenth Amendment. These early cases were clearly important in setting the stage for the landmark Brown v. Board of Education ruling in 1954.

It has been well established that Brown failed to produce immediate reductions in elementary and secondary school segregation (Orfield, 1983; Boozer, Krueger, and Wolkon, 1992; Clotfelter, 2004). Given this, it is perhaps unsurprising that it also failed to produce immediate gains in black collegiate enrollment. In fact, several of the most notable standoffs in the protracted battle for educational integration in the South occurred in higher education. More than five years after the Brown decision, a violent confrontation erupted when James Meredith attempted to enroll in the University of Mississippi, with the backing of a federal court order, and Governor Ross Barnett called in state troopers to block Meredith’s entry. The next year, in Alabama, Governor George Wallace made his "stand at the school house door" in an attempt to block two black students from enrolling in the University of Alabama.

Racial gaps in collegiate attainment have been stubbornly persistent. The strongest gains for black students relative to white students have occurred at the margin of college enrollment, with substantially smaller gains in BA attainment (where gaps 
actually grew for women). Comparing collegiate outcomes for cohorts born in 1935 to those born in 1970, the ratio of the share of blacks with some college to whites with some college increased from .56 to .68 for men and from .75 to .78 for women. At the BA level, black men made modest gains relative to white men, though among women the black-white ratio in BA receipt fell from .74 to $.51 .^{5}$ Much of the black relative gain can be attributed to a "composition" effect, as the black population shifted from the South, where college participation is low for both races, to the North, where participation rates are higher.

\section{B. Affirmative Action Policy in College Admission}

In 1965, President Lyndon Johnson gave a speech at Howard University in which he called for “... not just equality as a right and a theory, but equality as a fact and equality as a result.” In the years thereafter, many leading colleges and universities instituted affirmative action programs "to recruit minority applicants and to take race into account in the admissions process by accepting qualified black students even if they had lower grades and test scores than most white students” (Bowen and Bok, 1998, p. 7). These policies led to substantial increases in the representation of black students at the highly selective institutions where they were used (Bowen and Bok, 1998). They could not, however, have had large effects on overall college access, as a precondition for the use of any "preference" in admission is that admissions are selective in the first place, and Kane (1998) estimates that no more than $20 \%$ of colleges and universities in the United States operate selective admission policies. Even among selective colleges, affirmative action in the admission process was a matter of institutional choice, not a

\footnotetext{
${ }^{5}$ Authors' calculations using the 2000 IPUMS 5\% sample.
} 
national policy. ${ }^{6}$ Whether institutions considered race at all and in what measure was a policy determined at the level of individual colleges and universities, and affirmative action policies were adopted largely out of a sense of institutional mission.

While the judiciary began, with the Adams decisions in the 1970s, to require states to take more proactive steps to dismantle the legacy of separate and unequal public systems of higher education, the institutional practice of affirmative action to close racial gaps in admissions also came under judicial scrutiny. The 1978 Bakke case concerned a University of California at Davis policy that set aside a number of places in the medical school entering class for black students. ${ }^{7}$ A sharply-divided Supreme Court found this sort of explicit quota to violate Title VI of the Civil Rights Act, but at the same time affirmed the more general proposition that admissions officers could "take race into account” as one factor among many in the admissions decision. ${ }^{8}$

Affirmative action policies in higher education came into question again with a 1992 challenge to the admissions process at the University of Texas (UT). A district court struck down UT's “two track” admissions system while upholding the broad use of racial preferences; even this, however, was struck down by the Fifth Circuit Court of

\footnotetext{
${ }^{6}$ Selective universities in the South, in general, did not take proactive steps to increase the representation of black students in their classes in the early 1970s. The underrepresentation of black students in the South was particularly apparent at public flagship institutions, including the University of Mississippi, the University of Virginia, and the University of North Carolina. Following litigation in the 1970s [Adams v. Richardson, 1972 and Adams v. Califano, 1977], many states - including Virginia and North Carolina - made dramatic progress in increasing the representation of black students at their flagship public institutions. Mississippi, however, continued to lag and in 1992 the Fordice decision held states which had had segregated systems of higher education responsible for going beyond race-neutrality in their policies.

${ }^{7}$ The 1974 DeFunis case foreshadows the divided court seen in the Bakke decision. In DeFunis, the Court chose not to rule on the question of whether professional schools (in this case the University of Washington Law School) could give preference in admissions to minority applicants. Instead, the Court decided that the case was moot as the plaintiff had matriculated to another law school.

${ }^{8}$ The tie-breaking opinion was written by Justice Lewis Powell, who rejected the idea that "societal discrimination" was sufficient to justify racial preference as the individuals disadvantaged by such policies were not responsible for the wrongs suffered by minorities. He instead endorsed the idea that "diversity" is a compelling state interest that justifies the otherwise suspect consideration of race.
} 
Appeals on appeal, on the grounds that the goal of a diverse student body is "not of sufficient compelling interest to support the use of race as a factor in admissions.” (Hopwood v. State of Texas, 78 F.3d 932, $5^{\text {th }}$ Circuit 1996). The Supreme Court, in turn, refused to hear the case. This left racial preferences illegal in the states governed by the $5^{\text {th }}$ Circuit, but legal elsewhere.

The next battleground was California. In 1995, the University of California (UC) Board of Regents voted to end the use of race preferences in admissions. Shortly thereafter, in November 1996, voters in California passed Proposition 209, outlawing the use of racial preference in the areas of public employment, public education, and public contracting. ${ }^{9}$

Given mounting questions about the legal status of affirmative action after the Hopwood case and the mounting national political pressures against affirmative action, it was inevitable that a legal challenge to a major university's affirmative action policies that would make it to the Supreme Court. Two University of Michigan cases, ${ }^{10}$ initiated in 1997, were decided by the Supreme Court in 2003. The decisions endorsed as justifications for affirmative action both the on-campus benefits derived from a racially

${ }^{9}$ After Hopwood and 209, admission of black students plummeted at the University of Texas at Austin and at the flagship UC campuses in Berkeley and Los Angeles. The effects were far less dramatic at other, less competitive campuses in each state. Both California and Texas quickly developed alternative admission strategies that were facially race-neutral but designed to increase minority representation. In Texas, public high school students graduating in the top decile of their high school classes were guaranteed admission to any public university in Texas. In California, high school students graduating in the top 4\% were guaranteed admission to the UC, though not necessarily to its most selective campuses. Called " $\mathrm{x}$ percent” plans, these alternatives took advantage of substantial segregation by race at the elementary and secondary levels to increase the representation of minority students, and were accompanied by substantial outreach efforts directed at high schools that traditionally have sent few students to the UT and UC. Perhaps not surprisingly (Loury et al, 2003, amicus brief), these plans did not suffice to restore the minority representation attained under affirmative action, particularly at the top UC campuses.

${ }^{10}$ The first lawsuit (Gratz v. Bollinger), filed in October of 1997 against the University of Michigan concerned the undergraduate admissions process. The second (Grutter v. Bollinger), filed in December of 1997, concerned the law school admission process. The cases were heard en banc at the $6^{\text {th }}$ Circuit. 
diverse educational environment and the societal importance of producing a cadre of minority leaders and professionals (see Goldstein, 2004, for further analysis). In the second decision (Grutter v. Bollinger), Justice O’Connor, unwilling to endorse racial preferences in admissions in perpetuity, made her prediction that the need for such preferences would disappear within 25 years.

\section{Effects of Affirmative Action in College and University Admission}

There is no question that pro-active efforts to recruit and admit students from underrepresented groups produced sizable gains in the representation of black students at the most selective colleges and universities. Among the selective institutions studied in The Shape of the River, the percentage of black students rose from less than $1 \%$ in the 1951 entering class to about 5\% for the class starting in 1976 (Bowen and Bok, 1998). Similarly, Blackwell (1987) finds that the share of black students enrolled at Ivy League universities increased from 2.3 percent in 1967 to 6.3 percent in 1976; shares in other "prestigious" institutions increased as well from 1.7 percent to 4.8 percent. By comparison, 2000 Census data on racial disparities in aggregate collegiate attainment in these two cohorts suggests much smaller changes. Between the 1949 birth cohort (corresponding to college enrollment in 1967) and the 1958 birth cohort (corresponding to college enrollment in 1976), the ratio of black male college graduates to white male college graduates remained unchanged at 0.44 while the ratio of black men to white men with some college edged up from 0.68 to 0.72 . Plainly, the large jumps in black representation seen at the most selective colleges did not accrue across the spectrum. Less selective colleges had fewer options for increasing black attendance, and financial constraints among many less affluent institutions may have limited their capacity to 
provide aid to use tuition discounts (i.e. financial aid) for this purpose. To a substantial extent, college admission preferences for black students served to change the distribution of students among colleges, dramatically increasing representation at relatively selective colleges, rather than producing a large expansion in the black college-going pool.

The precise mechanics of institutional admission policies are not widely understood. As noted earlier, the courts have explicitly prohibited mechanical approaches to affirmative action in the form of quotas (Bakke) or "points" (Gratz), and most selective colleges employ ‘holistic’ evaluations in admissions that are not easily quantified. Still, by examining average admissions probabilities among groups defined by important determinants, like SAT scores, it is possible to get an idea of the role of race and of academic qualifications in admissions. Using comprehensive admissions records from a number of institutions, Bowen, Kurzweil, and Tobin (2005) provide a detailed examination of the extent to which race (as well as other factors such as legacy or athletic status) affects the probability of admission, holding SAT scores constant. They have generously provided us extracts from their data. Confidentiality requirements require that the data be presented only for groups of institutions, which we define by institutional selectivity. ${ }^{11}$

Admissions profiles are shown in Figure 2, for groups of institutions arranged by selectivity and control. Broadly, the difference between the likelihood of admission of black and white applicants with the same SAT score is largest in the broad middle of the

\footnotetext{
11 These data are from the Expanded College and Beyond study assembled by the Andrew W. Mellon Foundation, and describe the 1995 admissions cycle. We divide the Mellon institutions into public universities (Pennsylvania State University, UCLA, and the University of Virginia) and three selectivity groups of private institutions: Groups 1 (Harvard, Princeton, and Yale), 2 (Columbia, the University of Pennsylvania, Swarthmore, and Williams), and 3 (Barnard, Bowdoin, Middlebury, Oberlin, Pomona, and Wellesley).
} 
pool of applicants. At the very top - SAT scores over 1500 - both black and white applicants are very likely to gain admission, though at the most selective colleges racial preferences remain substantial; at the bottom, few students of either race are admitted. Adding additional "controls” would not alter the basic pattern of differences in admission by race.

Without the preferences indicated by Figure 2, there would be many fewer-as we discuss below, only about one-third to one-half as many—black students admitted to the Expanded College and Beyond institutions. The policy question at the center of our empirical analysis is whether there will be enough black students at the highest SAT scores 25 years from now to yield a critical mass of minority students even under raceblind criteria. In effect, if the same admissions profiles are applied to black and white applicants, what will be the representation of black students in the pool of students likely to receive admission offers?

\section{Section 3. Projections}

\section{A. Methods and Data}

Our approach to projecting the pool of applicants to selective colleges and universities takes into consideration expected changes in the relative distributions of black and white family incomes and in the pre-collegiate achievement of black and white youth over the next quarter century. We begin by projecting the relative distributions of black and white family income, which are likely to converge somewhat in coming years. As SATs depend heavily on family income, increases in black families' relative incomes will lead to increases in black students' relative scores. This will, however, almost 
certainly understate the overall progress in black relative test scores. As noted earlier, the black-white gap conditional on income is large (Jencks and Phillips, 1998) but mutable. In one set of estimates, we assume that the conditional (on income) gap will fall at the same rate over the next 25 years as has the unconditional gap over the last quarter century. This is almost certainly too optimistic, as the entire gain over the last 25 years occurred in the first ten years of that period; more recent data indicate growing blackwhite gaps. We also present somewhat less optimistic, but still unrealistically so, estimates based on simulations in which we assume that the school quality gap between black and white students is equalized. ${ }^{12}$

We use college admissions as a metric for assessing the substantive importance of our projected changes in test score distributions. With estimates of current application behavior and admissions probabilities by student race and qualifying test score, we simulate admissions to the four groups of selective colleges in the ECB data, using both current test score distributions and our simulated distributions and applying both racesensitive and race-neutral admission rules. These simulations allow us to assess whether it is plausible, as Justice O’Connor presumes, that there will be enough high-scoring blacks in 25 years that race-blind admissions rules will admit as diverse a class as is admitted using affirmative action today.

\footnotetext{
${ }^{12}$ Closing the racial gap in school quality might occur, for example, if perfect racial integration of the schools could be accomplished. Even in such an implausible scenario, our estimates overstate the impact on black-white gaps: One channel by which income affects test scores is by purchasing access to better schools, so by combining income-based progress and integration gains we double-count part of incomes' contribution.

Across-the-board increases in school quality are also possible, but will not have large effects on black-white gaps unless either the schools attended by black students improve substantially relative to those attended by whites or a constant quality improvement has larger effects on black students. There is some evidence supporting the latter (Krueger and Whitmore, 2002), though we judge the prospects for substantial closing of the black-white gap through this channel as limited.
} 
We rely on several data sources. For our estimate of the baseline distribution of college preparedness by race and family income, we use a data set containing observations on approximately one-third of students from the high school class of 2000 who took the SAT college entrance exam. We use the public-use microdata sample of the 2000 Census (from IPUMS—Ruggles, et. al., 2004) as our source for current family income distributions, and as the basis for our projections of future distributions. Our estimates of the rates of change in black-white test score gaps derive from the NAEP Long-Term Trend data (NCES, 1999), a time-series of scores on an unchanging test over the last quarter century. Finally, application and admission outcomes for a set of selective colleges and universities are calculated from the aforementioned Expanded College and Beyond data set, which describes the cohort entering college in the fall of 1995; we compute denominators for application rates by comparing these data to data on 1995 SAT-takers.

\section{B. Projections of Test Score Distributions}

Figure 3 displays the distribution of SAT scores for blacks and whites in 2000. While the distributions are similar in shape, the mean for black students is about 200 points lower than that for white students, resulting in extreme underrepresentation of black students at the highest scores. The bottom panel of the figure shows the fraction of students at each SAT score who are black. ${ }^{13}$ Blacks are substantially underrepresented (relative to their share of test takers) at every score above the grand mean of 1000 . This underrepresentation is most severe at the rightmost tail: In the 2000 cohort depicted here,

\footnotetext{
excluded.

${ }^{13}$ The sample here and elsewhere consists only of white and black SAT-takers; other races are
} 
there were about 250 white students who earned perfect scores of 1600 on the SAT, but only 2 black students. Similarly, there were over 5,000 whites with scores of 1500 or above but only 41 blacks. To maintain the current representation of black students at the most selective schools — where 65\% of admitted students have SAT scores above 1400 under admission policies that do not consider race directly, black academic progress must substantially reduce the under representation in Figure 3.

\section{Income convergence}

Among families with children aged 15-17 in the 2000 census, average black family incomes are about \$34,500—nearly half_less than whites, and the median black family was below the $25^{\text {th }}$ percentile of the white family income distribution. ${ }^{14}$ This gap is attributable partly to differences in family structure between races--57\% of black families and $24 \%$ of white families containing a 15 to 17 -year-old child have only one parent present—and partly to differences in labor market participation and outcomes.

Estimates of the intergenerational transmission of incomes indicate that, on average, somewhere between 40 and 60 percent of the gap between a father's income and the mean income will be closed by his son (Mazumder, 2000, is at the low end of this range; Solon, 1999 is at the high end). Estimates of the correlation of income or wealth across generations at the family level are within the same range, though perhaps near the lower end (Chadwick and Solon, 2002; Solon, 2002). ${ }^{15}$

\footnotetext{
${ }^{14}$ We have also estimated our projections using families with one member between the ages of 36 and 50 as the relevant universe, with similar results.

${ }^{15}$ We do not separately model changes in family structure and in incomes conditional on family structure, though the estimates cited here for the intergenerational correlation of family incomes reflect both. To the extent that black family structures converge toward white structures more quickly than would be expected given current income gaps, we will tend to understate the potential for family income convergence.
} 
While it is between-group convergence that is the focus of our analysis, most current estimates of the intergenerational transmission of income derive from samples of blacks and whites, assuming no distinction between between-group and within-group parameters. ${ }^{16}$ There are several reasons to expect that this might be unreasonable. First, black incomes did not converge toward those of whites for the first several centuries of black presence in North America, although the correlation in income between fathers and sons was undoubtedly well below 1 . This suggests that mean regression could go on within groups even when—for reasons of discrimination or for other reasons — there is little or no convergence within groups. Second, the rate of within-group convergence may well be different for blacks than for whites. (Mazumder, 2000, finds little indication of differences, but he has low power against reasonable alternatives.) Hertz (forthcoming) argues that persistent poverty among very low income black families drags down estimates of intergenerational mean reversion, suggesting that pooled estimates may overstate between-group convergence. Finally, even if we accept the accuracy of current estimates for between-group convergence, there is no guarantee that the rate of intergenerational transmission of income in the future will be the same as it was in the past. For example, an increase (or decrease) in the returns to skills could cause the speed of intergenerational transmission to increase (or decrease). ${ }^{17}$

Nonetheless, one piece of evidence does suggest that we would not have gone too far astray had we used a 0.40 to 0.60 coefficient of intergenerational mobility to project

\footnotetext{
${ }^{16}$ It is mildly reassuring that Borjas (1992) finds an intergenerational elasticity of around 0.60 when he allows for the effects of "ethnic group capital," although it is unclear whether the same elasticity should be applied for our purposes.

${ }^{17}$ The rise in inequality over the last quarter century likely caused black-white convergence to be lower than it would otherwise have been: Increases in black relative skills were offset by the deteriorating wages of low- and mid-skill workers.
} 
the black-white income gap in the past. Consider the following: In 1969, the average 30- to 39-year-old black male worker — who had attended separate and unequal schools and entered the labor force before the Civil Rights Act of 1964 barred discrimination earned 37 percent less than the average white worker. Based on the coefficient of intergenerational transmission of earnings alone, this gap would have been expected to close to 15 to 22 percent for the next generation. The actual earnings gap for men in their 30's in 1999 — roughly one generation beyond the same age range in 1969 — was 19 percent, well within the range of the forecast. This accurate forecast may just be a coincidence, but at least it was not wildly off (Krueger, 2003). Applying it to another generation, the black-white earnings gap would be projected to close to 6 to 13 percent when members of the third generation reach their 30's, around a quarter century from now.

For our projections, we take the middle of the consensus range, and assume that the gap in incomes between white and black families will be half as large in the next generation as it is today. For the reasons discussed above, we suspect that this is more likely to overstate than to understate the rate of convergence. It certainly overstates recent experience: As noted earlier, substantial changes in black family structures have kept the family income gap larger than the decline in individual earnings gaps would have implied. As continued relative deterioration of black family structures is unlikely, however, the $50 \%$ per generation figure seems a reasonable estimate for the rate of change of the unconditional black-white income gap going forward.

Figure 4 displays histograms of black and white family incomes in 2000 from the decennial Census. As noted earlier, the actual black-white gap in mean log incomes was 
nearly 0.77 (corresponding to a gap of $57 \%$, or $\$ 13,500$, at the mean) in that year, so the above assumptions imply that it will shrink by about 0.38 log points over the next quarter century. Our projections of the future black income distribution (relative to whites), then, are obtained by inflating the income of each black family in the 2000 data by $32 \%$ $(=\ln (1+0.38)-1)$. The resulting distribution is indicated by the dotted line on the figure. ${ }^{18}$ With this projection, the fraction of black families with incomes between $\$ 80,000$ and $\$ 100,000$ will increase by $69 \%$ (from $4.7 \%$ to $8.0 \%$ ), while the fraction with incomes between $\$ 25,000$ and $\$ 30,000$ will fall by $83 \%$ (from $7.6 \%$ to $6.3 \%)^{19}$ These changes provide re-weighting factors that can be used to estimate the effect of economic progress on black test score distributions.

Our SAT sample records students’ self-reports of their family income in 13 categories, so we compute re-weighting factors from the census data for each of these categories. To illustrate: Recall that we project that the number of black families with incomes between $\$ 80,000$ and $\$ 100,000$ will rise by $69 \%$ over the next quarter century In our counterfactual SAT distribution, then, we count each black SAT taker with a family income in this range 1.69 times. This has the expected result that re-weighted black average scores are higher (by about 19 points) than were unadjusted averages, as increases in the fraction of blacks coming from high-income families produce upward shifts in the SAT distribution. It also implies a small (about $0.7 \%$ ) increase in the black

\footnotetext{
${ }^{18}$ Census demographic projections indicate that the population of 17 -year-old blacks will grow by 14.9\% between 2000 and 2025, while the corresponding white population will shrink by 8.4\% (from http://www.census.gov/ipc/www/usinterimproj/). This demographic growth, not incorporated in Figure 4, can be expected to expand the number of blacks (and shrink the number of whites) at each income level. We do not include this in our projections, as expansions of black population shares arguably have commensurate effects on the "equal representation” goalposts.

${ }^{19}$ Of course, real income growth will raise both black and white incomes over the next quarter century. This should be expected to alter the figures on the x-axis of Figure 5, but absent changes in inequality should not change the shape of the distribution. Our approach implicitly assumes that it is relative income --not its absolute level -- that determines relative SAT scores.
} 
SAT-taking rate, as SAT-taking rates are higher among higher-income families. The projected test score distribution is shown as the "income counterfactual" series in Figure $5 .^{20}$

\section{Test Score Convergence}

Our first set of estimates assume zero convergence of test scores conditional on family income, which might be thought of as a reasonable lower bound for test score prospects for the next quarter century. An upper bound is provided by assuming that black-white gaps close as much within income groups in the next 25 years as did unconditional gaps over the last 25 years. Referring back to Figure 1, in the long run there has been some narrowing in the gap between black and white test scores among 17 year old students. Regression lines fit to the age-17 NAEP black-white difference at the $90^{\text {th }}$ percentile- this is likely most informative about the SAT-taking populationindicate that blacks have gained $0.44 \%$ of a standard deviation per year relative to whites on the math exam, and $1.59 \%$ of a S.D. annually on the reading exam.

The verbal and math components of the SAT exam have standard deviations of approximately 100 points each, so the NAEP trend, if it continues at the same rate, would imply that the black-white gap in SAT scores should close by just over 50 points over the next quarter century. To incorporate this trend into our analysis, we simply add this many points to each black SAT score in the 2000 data. The dashed line in Figure 5 shows the resulting histogram in the income-reweighted data.

\footnotetext{
${ }^{20}$ One disconnect between our simulation and the educational process is worth noting. Although the reasons why family income affects student performance on the SAT are unclear, it is quite likely that the entire stream of family income over a child's time at home is relevant, not just income in the year he or she takes the SAT. Unfortunately, we lack data on family income in earlier years.
} 
This almost certainly overestimates the extent of black score growth over the next quarter century. As Figure 1 indicates, essentially all of the progress over the last twenty five years in NAEP scores occurred in the 1980s, with growth of the racial gap during the 1990s. It would take substantial optimism to assume that future progress will occur at the rate seen over the full NAEP period rather than the much slower rate seen recently, particularly as we are assuming that this progress will be in addition to that generated by income convergence, where the NAEP estimates do not condition on family incomes.

\section{Equalizing school quality}

An alternative approach to projecting the distribution of black scores is to imagine specific interventions into the educational process. One particularly ambitious—and, it must be admitted, wholly politically implausible—intervention might be to fully integrate schools. The average black SAT-taker attends a high school where 52\% of (black and white) SAT-takers are black, while black students are only $8 \%$ of SAT-takers at the average white SAT-taker's school (Card and Rothstein, 2004). Schools are not just separate, but also unequal: Anecdotally, black students attend substantially lower-quality schools, on average, than do whites, and our data confirm this impression.

It is unlikely that interventions in the educational process can have larger effects on black-white test score gaps than to close this school quality gap. Thus, projections that assume the quality gap will close provide an alternative optimistic view of the prospects for conditional-on-income progress. ${ }^{21}$

${ }^{21}$ Of course, to the extent that black families will make use of rising incomes to buy their way into higher-quality schools (either by paying tuition at private schools or by purchasing homes near good public schools), this strategy also double-counts the effects of income growth. 
We construct a crude estimate of school quality as the fixed effect in a regression of SAT scores on a rich vector of student background characteristics. ${ }^{22}$ Estimated this way, the student-level standard deviation of school quality is 69 SAT points, and the median black SAT-taker attends a school whose quality is 32 points lower than that of the median white SAT-taker's school. To implement the "integration" approach, we match corresponding percentiles of the black, white, and overall school quality distributions, and re-assign the overall quality distribution to both blacks and whites. That is, we assume that those blacks who currently attend the best schools attended by black students will, in the integrated counterfactual, attend the best schools overall, and the same for whites. Our re-assignment has the effect of closing the black-white gap in mean scores (in the income-reweighted data) by 30 points, the gap in median scores by 34, and the gap at the $90^{\text {th }}$ percentile by $24 .^{23}$

Figure 6 shows the fraction of students at each score who are black in each of the counterfactual simulations (presented in Figure 5): Income growth only, income growth plus NAEP convergence, and income growth plus integration. By construction, the first simulation has the smallest effect, increasing the number of high-scoring (1400 or above) blacks by about $54 \%$ over its current low level. The integration scenario is next, producing (in combination with income convergence) a 109\% increase in high-scoring blacks. The most optimistic scenario is the one using NAEP trends, in which the number of high-scoring blacks increases by 225\%. Even under this counterfactual, however, the

\footnotetext{
${ }^{22}$ The regression includes full interactions of individual gender, race, and 13 family income dummies and of race with 100 (10 mother's by 10 father's) parental education dummies. Our approach ascribes both peer effects and any other school-level components of test score variation to school quality (Rothstein, 2004). In particular, we will overstate the importance of schools if there are any important unobserved aspects of individual background.

${ }^{23}$ These numbers are similar, but not identical, when the original SAT-taker weights are used.
} 
proportion of blacks scoring above 1400 will be about one quarter of the corresponding proportion of whites, with more extreme underrepresentation at higher scores.

\section{Admissions Projections}

Our interest is in how the projected changes in the relative distribution of the academic achievement (measured by test scores) of black and white students will alter the relative representation of black and white students among those admitted to selective colleges and universities under race-blind admission policies. To address this, we must convert SAT distributions to admissions rates. The observed admissions decisions of colleges and universities provide admission profiles, by SAT, for composite institutions of varying selectivity. We focus on four composite profiles of admissions outcomes defined as: Most selective private (Selective 1: Harvard, Princeton, and Yale), highly selective private (Selective 2: Columbia, the University of Pennsylvania, Swarthmore, and Williams), moderately selective private (Selective 3: Barnard, Bowdoin, Middlebury, Oberlin, Pomona, and Wellesley) and selective public (UCLA, University of Virginia and Pennsylvania State). ${ }^{24}$ We model expected admission to each of these "composite" schools, rather than to the individual institutions.

To calculate expected admissions under each of our simulations, we simply multiply:

Expected admissions $_{r}=\Sigma_{j}$ (Number of test takers N $_{j} x$

Application Rate ${ }_{j r} x$

Admission Rate $_{j r}$ )

\footnotetext{
${ }^{24}$ Several other schools in the Mellon database (the University of Illinois, Smith, and Macalester) are excluded from our analysis because large fractions of their applicants do not submit SAT scores.
} 
for each race (r) and SAT level (j). Under the current regime both application rates and admission rates differ by race. Under a race-neutral policy, blacks and whites with the same test scores would face the same probability of admission, conditional on application. We implement this by assigning the admission profile observed for whites to blacks, in effect assuming that both black and white students will face the admission probabilities indicated by the solid line in Figure $2{ }^{25}$ We also consider alternative policies that provide admissions advantages to students from the lowest income families (what some have called "class-based affirmative action”).

It is important to emphasize that our calculations are inherently static, as we do not explicitly model the changes in individual application behavior and college admissions policies that a shift to race-neutral admissions would entail. Most importantly, a large shift in admissions probabilities would likely lead to responses in black students' decisions about where to apply. At each SAT score, black students currently are substantially more likely than are whites to apply to the most selective institutions (see Figure 7, using the institutional data). This disparity is smaller at less selective institutions, where it largely disappears at the highest SAT scores.

One scenario that we think is unlikely is one of substantial increases in the rate at which high-scoring black students apply to elite colleges: As Figure 7 indicates, application rates among these students are already quite high. Indeed, using the SAT data, we calculate that well over half of blacks with SATs above 1500 send their scores-

${ }^{25}$ If application behavior is unchanged, the elimination of racial preferences will reduce the total number of admittees. As the share of students admitted under affirmative action is small, this effect is as well. Nevertheless, to the extent that colleges lower the race-blind admissions standards to compensate, we will very slightly overestimate the effect of affirmative action on black admissions shares. 
a proxy for application— to Harvard alone. ${ }^{26}$ This does not speak well for the prospects for increasing minority representation through better outreach to potential applicants, and we therefore focus on changes in the number of high-scoring blacks as the primary potential source of black-white convergence in the number of qualified applicants.

A plausible explanation for the existing racial differences in application rates is that black students respond to the admissions advantages they face at selective colleges and universities. If this is indeed the explanation, one might expect application rates to converge as admissions probabilities do. One piece of evidence that weighs against this expectation, however, is that at least in the short-run the elimination of race-conscious admission policies in Texas and California appears not to have altered the pattern of applications of high-achieving black students (Card and Krueger, forthcoming). In any event, in addition to estimates based on current race-specific application rates, we also consider a scenario in which black application rates come to resemble those of whites.

Table 1 presents simulations based on the assumption that black application behavior remains as it is today. The first row shows the actual representation of black students among those admitted at the four institutional composites in $2000 .{ }^{27}$ We define representation as blacks divided by blacks plus whites. This omits students of other races, so leads to higher estimates. Thus, where we calculate that $16.1 \%$ of black and white admissions at S1 institutions are of blacks, a more inclusive calculation would

\footnotetext{
${ }^{26}$ Card and Krueger (forthcoming) found substantial similarity between patterns seen in actual applications and those obtained by examining score reports.

27 Note that our analysis focuses on the pool of students admitted to composite institution types, not the actual representation of students in the entering cohort. There are presently substantial differences between black and white students in matriculation, which we expect would change with policy shifts such as the elimination of race-conscious admissions. We believe the most judicious strategy is to avoid projections of enrollment which necessarily rely on parameters that are difficult to project.
} 
indicate that only $10.4 \%$ of all admissions at these schools are of blacks (and 54.5\% are of whites).

The second row of the table shows the black share of admissions under the "race neutral" counterfactual, in which the observed white admission profile is applied to both blacks and whites. With current test score distributions, this would reduce the representation of black students by more than two-thirds, from $17.1 \%$ to $5.1 \%$, at the most selective private institutions (S1). Projected declines in the representation of black students are by no means limited to the most selective institutions, and are estimated at 55\% for public institutions, 58\% for the highly selective private institutions and $46 \%$ for the moderately selective private institutions. ${ }^{28}$ These are the gaps which black relative academic progress must close in order to realize Justice O’Connor's prediction that race preferences will no longer be necessary to accomplish what affirmative action is needed to accomplish today.

Row 3 of Table 1 applies the same race-neutral admissions rule to the first counterfactual SAT distribution, assuming income convergence but no additional progress in test scores. This produces small gains in the representation of black students relative to what would be seen today with the same admissions rules. For each institutional composite, we show the share of the gap between current black representation and that which would be seen with race neutral admissions today that our projected income-driven convergence would close. Only about one fifth of this gap is closed at the public, most selective and highly selective composite institutions. Gains are slightly larger at the moderately selective private institutions, closing 25.4 percent of the

\footnotetext{
${ }^{28}$ These figures amount to estimates of the current effects of affirmative action policies on black admissions shares.
} 
gap. It appears that reasonable income convergence will not, on its own, allow for the abolition of affirmative action without severely impacting black representation at elite colleges.

When we allow for additional progress via reductions in the black-white test score gap conditional on family income, however, we obtain considerable expansions of black admissions shares. These shares are shown rows (4) and (5) of Table 1, without and with expected income convergence. For public and less-selective institutions, narrowing of the test score gap combined with income convergence would go a considerable distance toward reproducing today's levels of diversity, if it can be assumed that application behavior does not change. This is less true at the most selective private institutions, where the black share would remain substantially lower than is observed today.

In the last two rows of the table, estimates of the representation of black students relative to white students under the alternative counterfactual of school integration (or of equalization in school quality) are presented. As one might infer from Figures 5 and 6, these projections are between the estimates with income convergence along and those under the assumed level of test score convergence, closing about $30 \%$ of the gap created by the shift to race neutral policies. Given the extent of progress that the school integration scenario entails, the extent to which it is surpassed by the test score convergence scenario underscores the optimism inherent in the latter.

Table 2 presents an identical analysis under the assumption that black application rates come to resemble those seen today among whites with similar SAT scores. Black shares are lower in each simulation in these tables, but the effects of income and test score convergence are similar. The evidence from Table 2 indicates that any declines in 
application rates of high scoring black students would exacerbate the drop in black representation produced by moving to a race-neutral admission policy. ${ }^{29}$

\section{Alternative Admissions Rules}

Racial minorities are not the only distressingly underrepresented group in elite colleges. Students from middle- and lower-class backgrounds, regardless of race, are also unlikely to have the SAT scores needed for admission under current admissions rules. Some observers (e.g. Kahlenberg, 1996) have proposed that elite colleges implement “class based affirmative action” (hereafter “CBAA”), giving preferences to low-income students akin to those now given to racial minorities. As blacks (and Hispanics) tend to have lower incomes than whites, some have even suggested that income-sensitive policies could be a means of admitting more black students without the legally suspect consideration of race per se. It is not clear, however, whether the raceincome correlation is strong enough to make family income a useful proxy for race. If it is not, CBAA will be a blunt tool for achieving racial diversity. What is more, it can only become blunter in the future, as ongoing narrowing of black-white income gaps will make black students even less identifiable in the income distribution and further worsen income’s efficacy as a proxy for race.

To illustrate the potential effects of class-based affirmative action both today and in the future, we apply this sort of admissions rule to our simulated SAT distributions. $21 \%$ of SAT-takers report family incomes of $\$ 35,000$ or less, roughly comparable to the 15\% who are black. We thus model a CBAA admissions rule as giving the same

\footnotetext{
${ }^{29}$ Holding application rates constant as admissions policy changes, black application rates give a much larger change in the representation of blacks with the move to race-blind admissions at the most selective schools (from a share of 0.171 to 0.051 ) than do white application rates, which lead to a projected change in share from 0.057 to 0.016 . To the extent that any change in application rates is a consequence of the policy shift, however, the best comparison is of row 1 in Table 1 to rows 2 through 8 of Table 2.
} 
admissions advantage to students with family incomes below this level as is today given to black students. The results are illustrated in Table $3 .^{30}$ Consideration of family income does, indeed, increase the representation of black students. However, because black students are only moderately overrepresented among the additional students admitted under income-based preferences, and because the students brought in under these preferences comprise only a small share of the baseline class, the effect on total black representation is relatively modest. Under our baseline assumption, with no convergence in income or test scores, the black share rises from $5.1 \%$ to $7.0 \%$ at the most selective private institutions and from $5.3 \%$ to $7.2 \%$ at public institutions.

When we turn to the simulation with income convergence, black overrepresentation among low-income SAT-takers shrinks, as does the effect of CBAA on black admissions shares. This is partially offset when we add to the simulation test score convergence, which produces substantial increases in the number of low-income blacks with mid-range scores, where preferences are strong. The share of black students among the additional students admitted under an income-based policy rises to nearly $22.1 \%$ at the most selective universities, $26.9 \%$ at schools in the next selectivity band, $25 \%$ at moderately selective schools and $22.6 \%$ at public universities. But the CBAA beneficiary pool remains small and the majority of this pool remains white, so we see relatively modest changes in the representation of black students.

\footnotetext{
${ }^{30}$ More low-income students than black students have SATs in the middle of the distribution, where preferences have the largest effects (Figure 2). As a result, a shift from race- to income-based admissions would, if the size of the preference is held constant, lead to more total admissions. To the extent that colleges respond to this by tightening admissions standards across the board (the alternative would be to expand the admissions pool, by as much as one quarter), black admissions shares will be lower than those shown in Table 3, as more black than white admittees are marginal admits.
} 


\section{Section 4. Conclusions}

Affirmative action is a feature of admissions rules at the nation's most selective colleges today, but it may not be in the future. The legacies of separate and unequal schooling and of labor market discrimination are reflected in the academic preparation of the current generation of black students. In an equal opportunity society, the effects of past discrimination on current generations will eventually asymptote to zero, though there is substantial uncertainty about the rate at which this might be expected to occur. In Grutter, Justice O’Connor suggests that affirmative action in admissions can only be considered constitutional as a temporary policy, and she forecasts it will not be necessary 25 years hence.

To provide a quantitative assessment of Justice O’Connor’s speculation, we consider the racial composition of today's admitted students as a baseline, and ask whether foreseeable progress in black economic and educational success can plausibly be expected to lead race-blind admissions rules to reproduce today’s race-conscious results in a quarter century.

We are most confident in predicting that economic progress will not be sufficient to yield as much diversity as is obtained by today's race-sensitive admissions policies. Under plausible assumptions about changes in the income distribution of black families in the next 25 years, the representation of black students at selective colleges under raceblind admissions will be only $42 \%$ of the status quo. Put another way, black economic gains over the next quarter century can be expected to provide only about $17 \%$ of the incremental representation that is provided by affirmative action today. 
This conclusion is not much changed if the future admissions policy is assumed to incorporate "class-based" affirmative action, in which students from families with low incomes are given preferences analogous to those given to racial minorities today. The correlation between race and family income, while strong, is not strong enough to permit the latter to function as a useful proxy for race in the pursuit of diversity. Moreover, the value of income as a proxy for race can only decline with increases in black incomes.

Similarly, we judge it unlikely that universities will be able to compensate for the abolition of race-based preferences through increased outreach toward and recruitment of minority students. Our exercise suggests that there will simply be too few high-scoring black students, and that they already apply to the most selective colleges at rates far exceeding those of white students with similar scores.

We do find a glimmer of hope, however, in our projections that incorporate increases in black test scores beyond those deriving from changes in family income. Our most optimistic simulations assume that, conditional on income, black students' scores relative to white students' will rise at the same rate over the next quarter century as a linear trend fit to past patterns. In this case, and if black student application behavior is assumed stable, we find that race-blind rules may approach the black representation achieved by affirmative action. This projection is undoubtedly upward biased, however, as the last 25 years saw two distinct regimes, with rapidly closing black-white gaps in the first period and deterioration in black relative performance since 1990. To extrapolate a linear trend a full quarter century into the future is to assume a dramatic turnaround from recent patterns, and sustained growth over a longer period than has been seen before. 
As an indication of the degree of difficulty of achieving this projection, we consider the effects of a wholly implausible intervention producing the complete integration of the nation's secondary schools. This, we estimate, would produce only a small fraction of the test score gains that would be needed to make Justice O’Connor's prediction a reality. Clearly, substantial progress in increasing black students’ precollegiate performance is critical to any hope of eliminating the need for affirmative action within the next generation. Absent such progress, the elimination of racial preferences in admissions, today or twenty five years from now, will lead to substantial declines in black representation at the nation's most selective colleges and universities. Our simulations, crude as they are, lead us to agree with Justice Ruth Bader Ginsburg's concurring opinion in Grutter, “From today’s vantage point, one may hope, but not firmly forecast, that over the next generation's span, progress toward nondiscrimination and genuinely equal opportunity will make it safe to sunset affirmative action.” 


\section{References}

Blackwell, James. 1987. Mainstreaming Outsiders: The Production of Black Professionals. 2d edition. Dix Hills, NY: General Hall.

Boozer, Michael, Alan B. Krueger, and Shari Wolkon. 1992. "Race and School Quality Since Brown v. Board of Education” Brookings Papers on Economic Activity. Microeconomics, Vol. 1992, pp. 269-338

Bond, Horace Mann. 1934. The Education of the Negro in the American Social Order. New York: Prentice Hall.

Borjas, George. 1992. "Ethnic Capital and Intergenerational Mobility," The Quarterly Journal of Economics, vol. 107, no. 1, February, pp. 123-150.

Bowen, William, and Derek Bok. 1998. The Shape of the River: Long Term Consequences of Considering Race in College and University Admission. Princeton University Press.

Bowen, William, Martin Kurzweil, and Eugene Tobin. 2005. Equity and Excellence in Higher Education (draft)

Card, David, and Alan Krueger. 1992. "School Quality and Black-White Relative Earnings: A Direct Assessment” The Quarterly Journal of Economics, Vol. 107, No. 1. (Feb.), pp. 151-200.

Card, David, and Alan Krueger. 1993. "Trends in Black-White Earnings Revisited.” American Economic Review, Vol. 83, No. 2, Papers and Proceedings of the Hundred and Fifth Annual Meeting of the American Economic Association. (May), pp. 85-91.

Card, David, and Alan Krueger. Forthcoming. "Would the Elimination of Affirmative Action Affect Highly Qualified Minority Applicants? Evidence from California and Texas.” Industrial and Labor Relations Review.

Card, David, and Jesse Rothstein. 2004. "Racial Segregation and the Black-White Test Score Gap.” Unpublished manuscript.

Chadwick, Laura, and Solon, Gary. 2002. "Intergenerational Income Mobility among Daughters.” American Economic Review, Vol. 92, No. 1. (March), pp. 335-44.

Clotfelter, Charles. 2004. After Brown: The Rise and Retreat of School Desegregation. Princeton.

Crain, Robert, and Rita Mahard. 1983. "The Effect of Research Methodology on Desegregation-Achievement Studies: A Meta-Analysis.” The American Journal of Sociology, Vol. 88, No. 5. (March), pp. 839-854. 
Donohue, John, and James J. Heckman. 1991. "Continuous versus Episodic Change: The Impact of Civil Rights Policy on the Economic Status of Blacks.” Journal of Economic Literature, 29, pp. 1603-1643.

Drewry, Henry, and Humphrey Doermann. 2001. Stand and Prosper: Private Black Colleges and Their Students. Princeton University Press.

Freeman, Richard. 1973. “Changes in the Labor Market for Black Americans,” Brookings Papers on Economic Activity 20, pp. 67-120.

Goldstein, Joel. 2004. "Beyond Bakke: Grutter-Gratz and the Promise of Brown.” Saint Louis Law Journal, v. 48, n. 899.

Hertz, Tom. Forthcoming. "Rags, Riches and Race: The Intergenerational Economic Mobility of Black and White Families in the United States." In S. Bowles, H. Gintis and M. Osborne, eds., Unequal Chances: Family Background and Economic Success.

Princeton, NJ: Russell Sage Foundation and Princeton University Press.

Jencks, Christopher, and Phillips, Meredith, eds. 1998. The Black-White Test Score Gap. Washington, D.C.: The Brookings Institution.

Kahlenberg, Richard D. 1996. The Remedy : Class, Race, and Affirmative Action. Basic Books.

Kane, Thomas J. 1998. "Misconceptions in the Debate over Affirmative Action in College Admissions.” In Gary Orfield and Edward Miller, eds., Chilling Admissions: The Affirmative Action Crisis and the Search for Alternatives. Cambridge, MA: Harvard Education Publishing Group.

Krueger, Alan. 2003. “The Supreme Court finds the 'mushball middle' on affirmative action” New York Times (July 23).

Krueger, Alan, and Diane Whitmore. 2002. "Would Smaller Classes Help Close the Black-White Achievement Gap?” In John Chubb and Tom Loveless, eds., Bridging the Achievement Gap. Washington, DC: Brookings Institute Press.

Loury, Glenn et al. 2003. Amicus brief in Grutter v. Bollinger and Gratz v. Bollinger. http://www.piperrudnick.com/db30/cgi-bin/pubs/UofMAmicusBrief.pdf

Mazumder, Bhashkar. 2000. "Earnings Mobility in the US: a New Look at Intergenerational Mobility”, mimeo.

National Center for Education Statistics (NCES). 1999. "Results Over Time--NAEP 1999 Long-Term Trend Summary Data Tables,” http://nces.ed.gov/nationsreportcard/tables/Ltt1999/ 
Orfield, Gary. 1983. “Public School Desegregation in the United States, 1968-1980,” Washington, D.C.: Joint Center for Political Studies.

Phillips, Meredith, Jeanne Brooks-Gunn, Greg Duncan, Pamela Klebanov, and Jonathan Crane. 1998. "Family Background, Parenting Practices, and the Black-White Test Score Gap,” in Christopher Jencks and Meredith Phillips, eds., The Black-White Test Score Gap. Washington, DC: Brookings Institution Press.

Ruggles, Steven, Matthew Sobek, Trent Alexander, Catherine A. Fitch, Ronald Goeken, Patricia Kelly Hall, Miriam King, and Chad Ronnander. 2004. Integrated Public Use Microdata Series: Version 3.0 [Machine-readable database]. Minneapolis, MN:

Minnesota Population Center [producer and distributor], www.ipums.org.

Rothstein, Jesse. 2004. “Good Principals or Good Peers? Parental Valuation of School Characteristics, Tiebout Equilibrium, and the Incentive Effects of Competition Among Jurisdictions.” Working Paper \#10666. Cambridge, MA: National Bureau of Economic Research.

Solon, Gary. 1999. "Intergenerational Mobility in the Labor Market," in Handbook of Labor Economics, vol. 3A, 1761-1800.

Solon, Gary. 2002. “Cross-Country Differences in Intergenerational Earnings Mobility.” Journal of Economic Perspectives, Vol. 16, No. 3 (Summer), pp. 59-66. 
Figure 1: Trends in Black-White gaps in Student Achievement, NAEP Test, Age 17

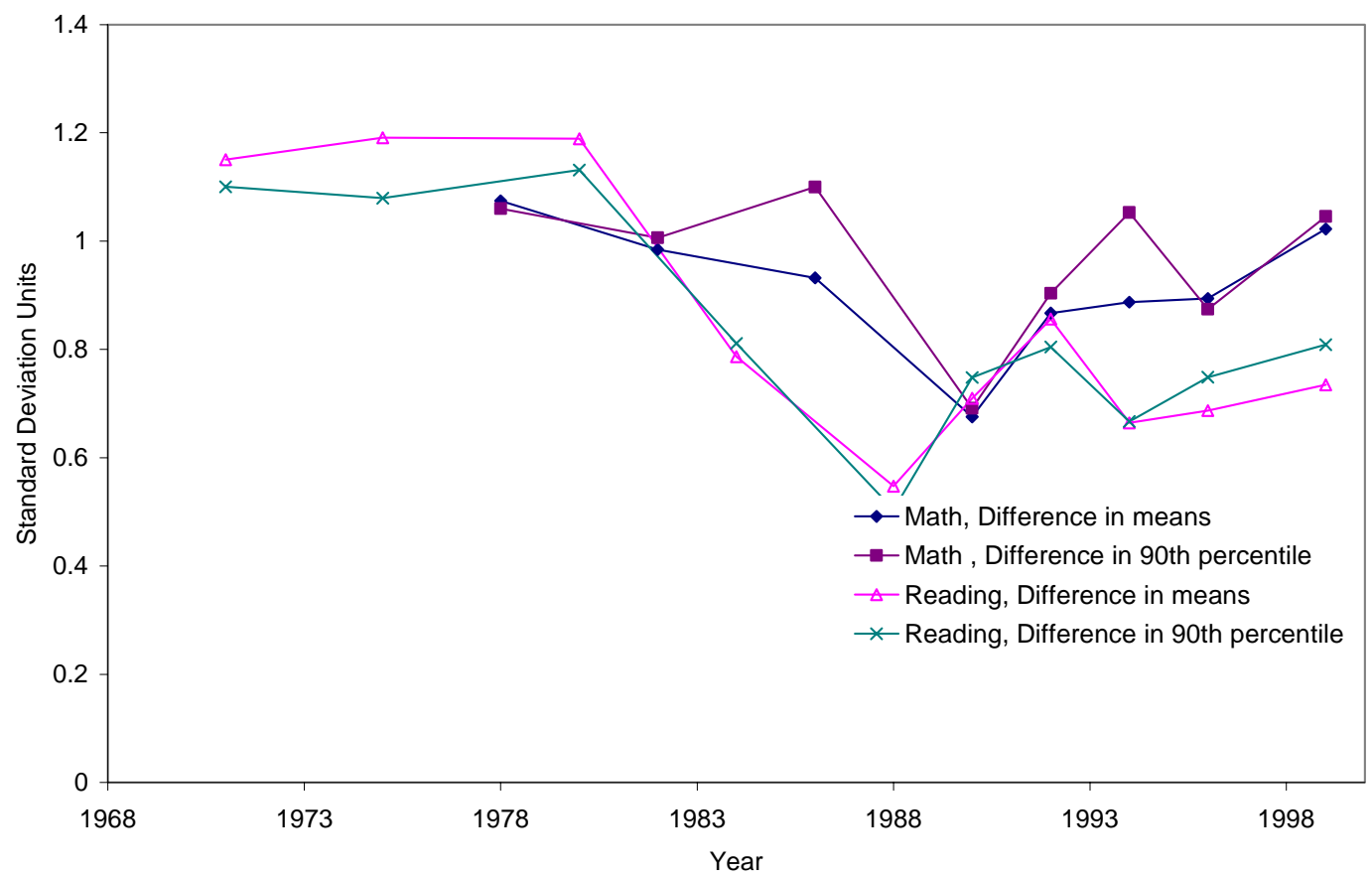

Source: NCES, 1999. 
Figure 2: Admission rates by type of institution and race
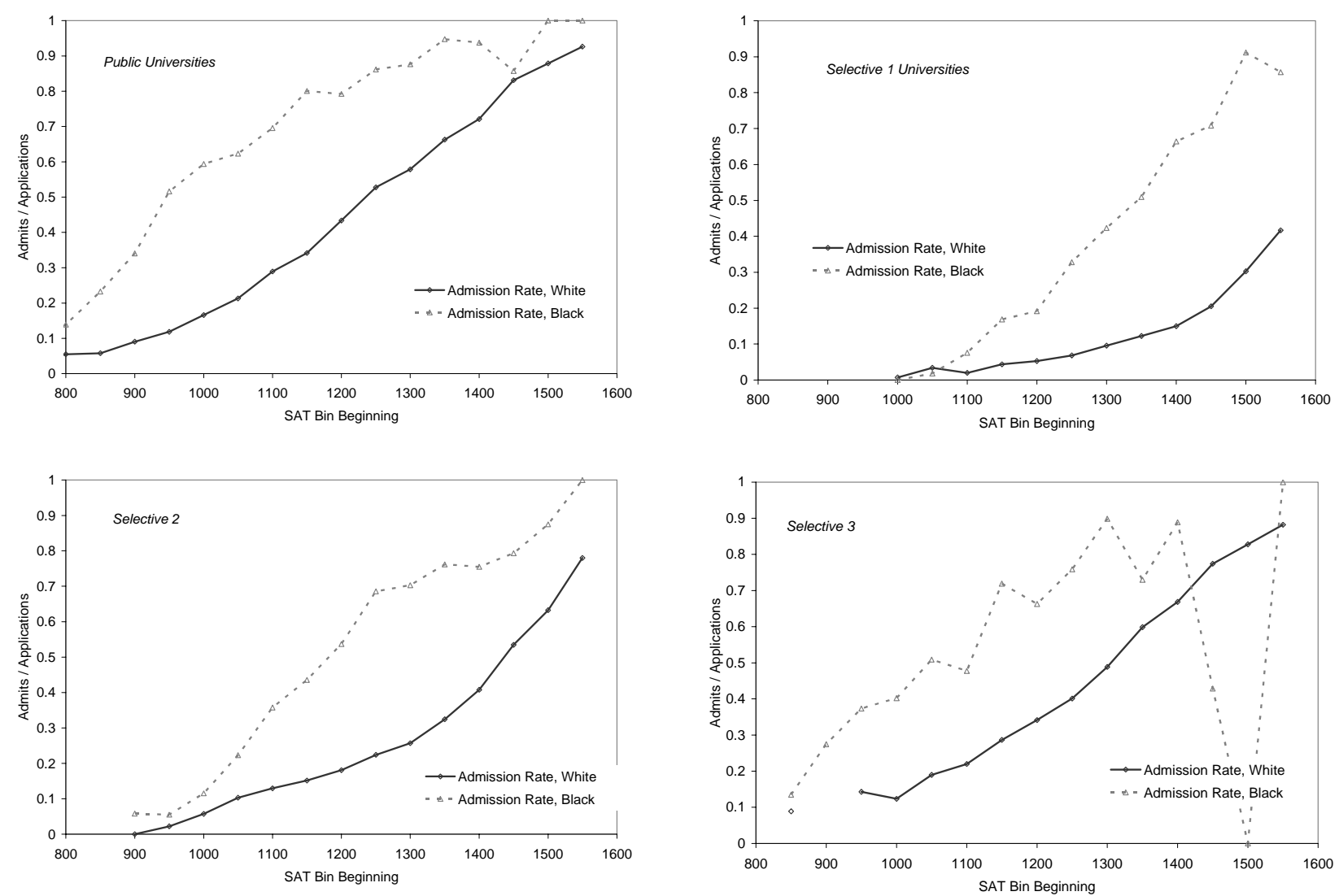

Source: Authors' calculations from Expanded College and Beyond. 
Figure 3: Distribution of SAT scores, black and white test takers

\section{Panel A}

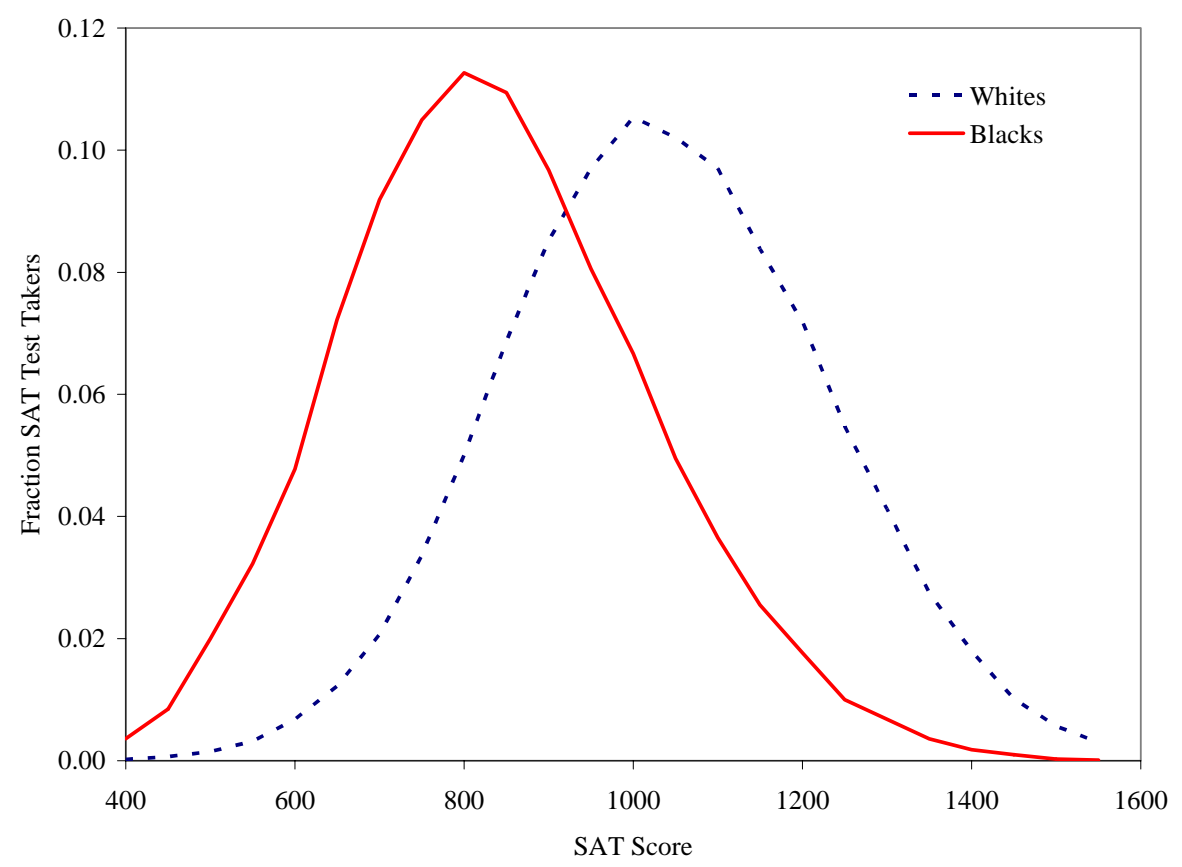

\section{Panel B:}

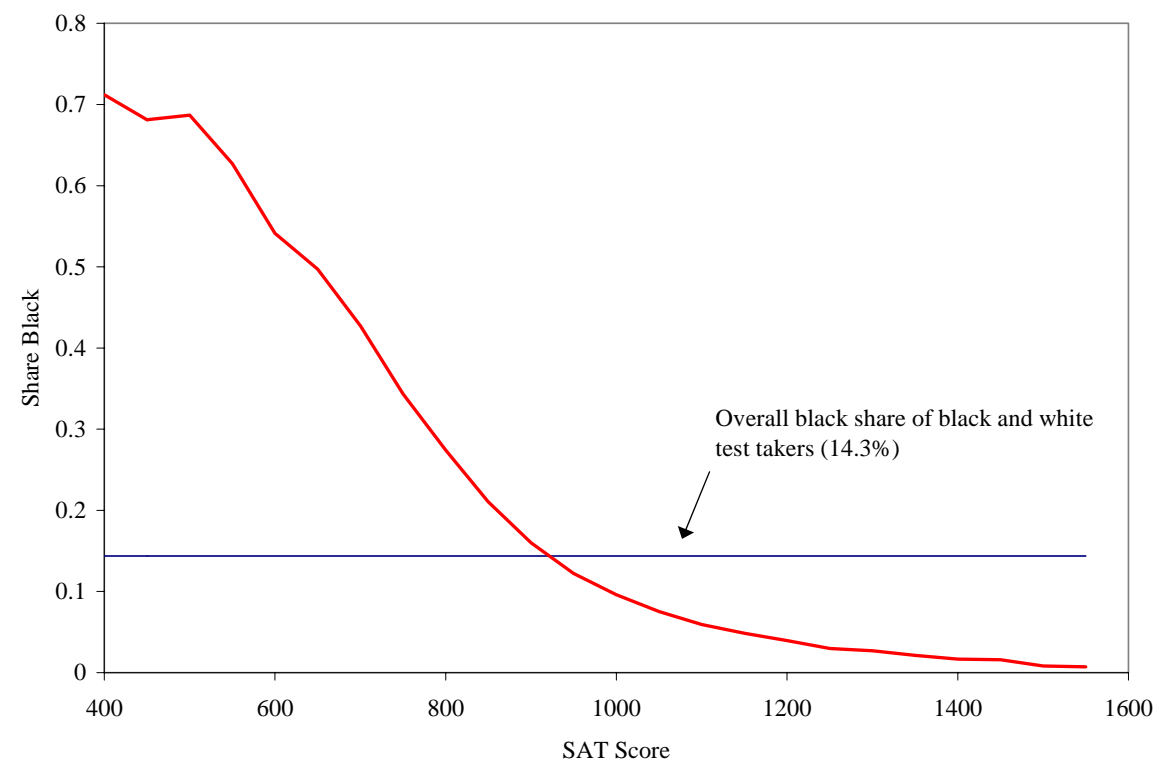

Source: Authors’ calculations from Test Takers Database, 2000 cohort. 
Figure 4: Black and white family income distributions, 2000 Census

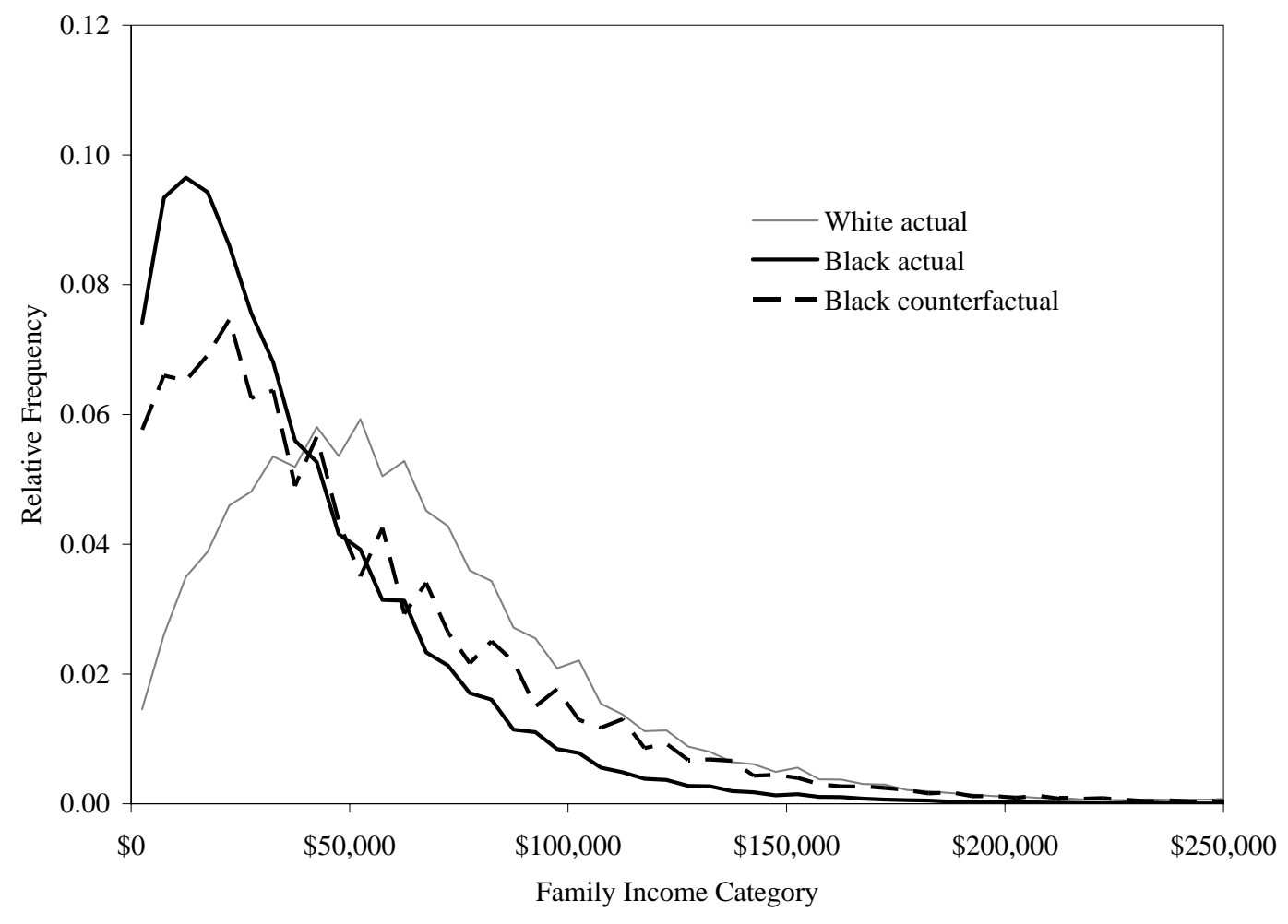

Source: Authors' calculations from 2000 Decennial Census Public Use Microdata Sample (Ruggles et al., 2004). 
Figure 5: Predicted effects of income growth on the distribution of test scores of blacks

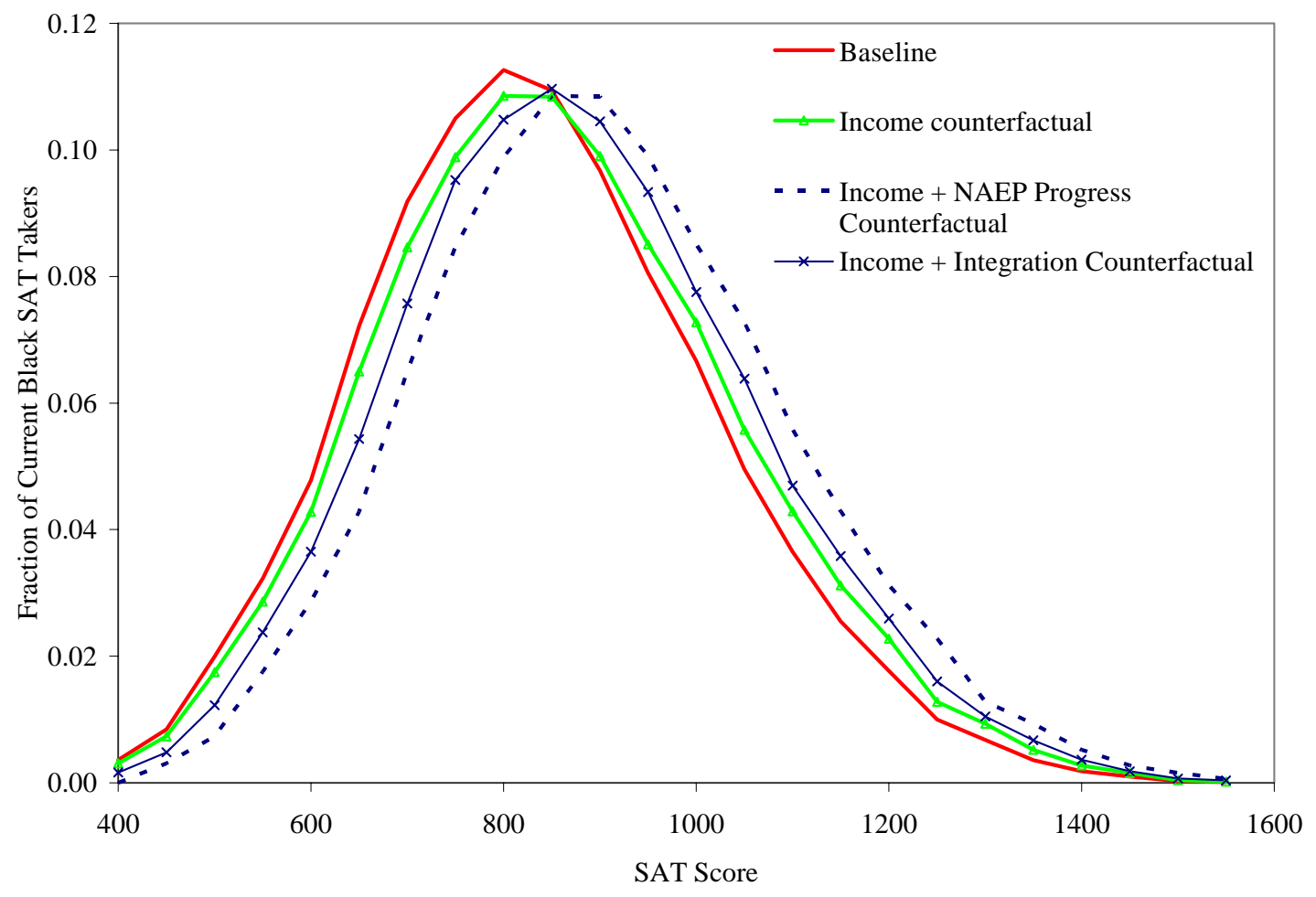


Figure 6: Black share of (Black and White) SAT-takers, by SAT Score

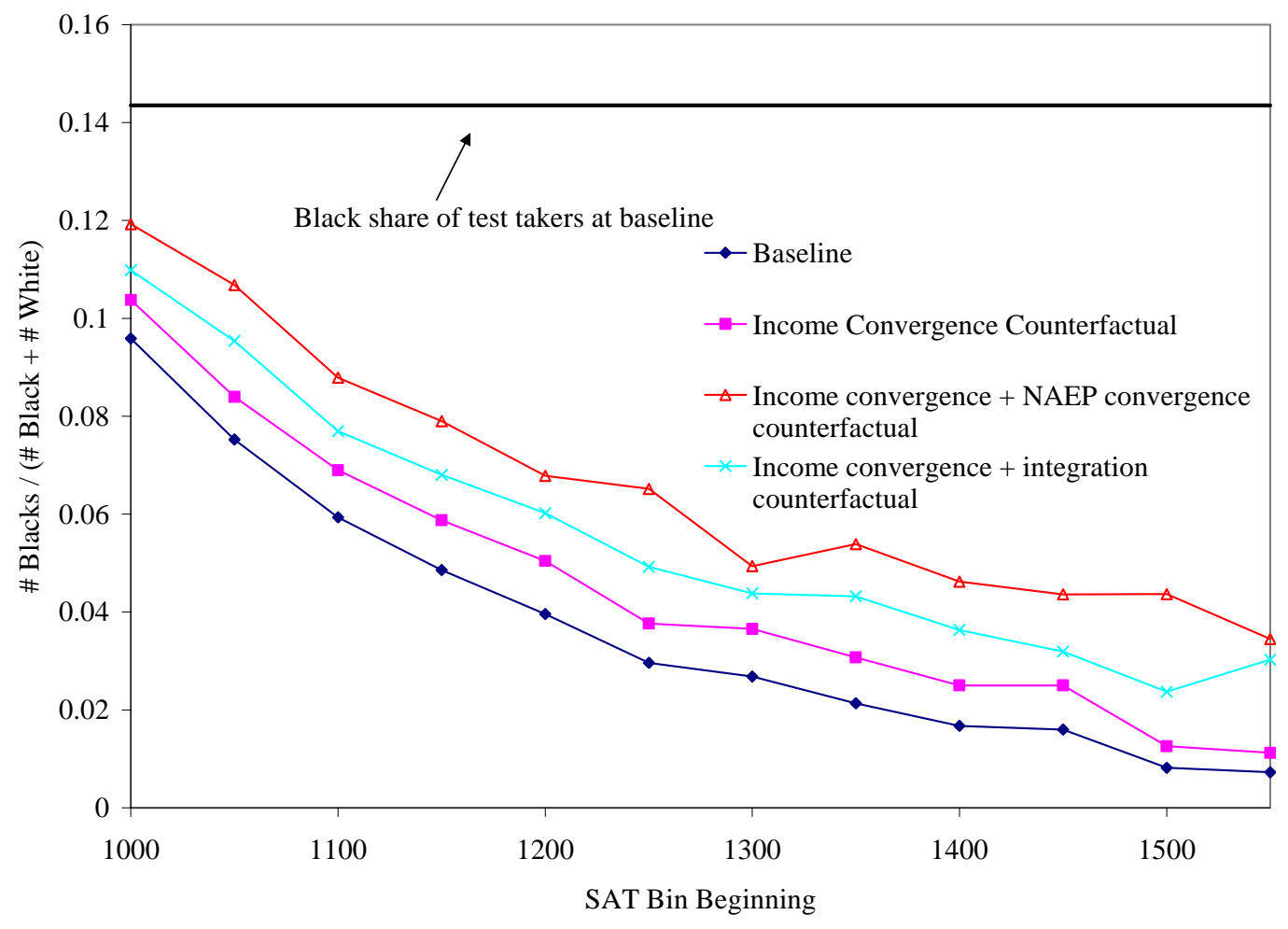


Figure 7: Application rates by type of institution
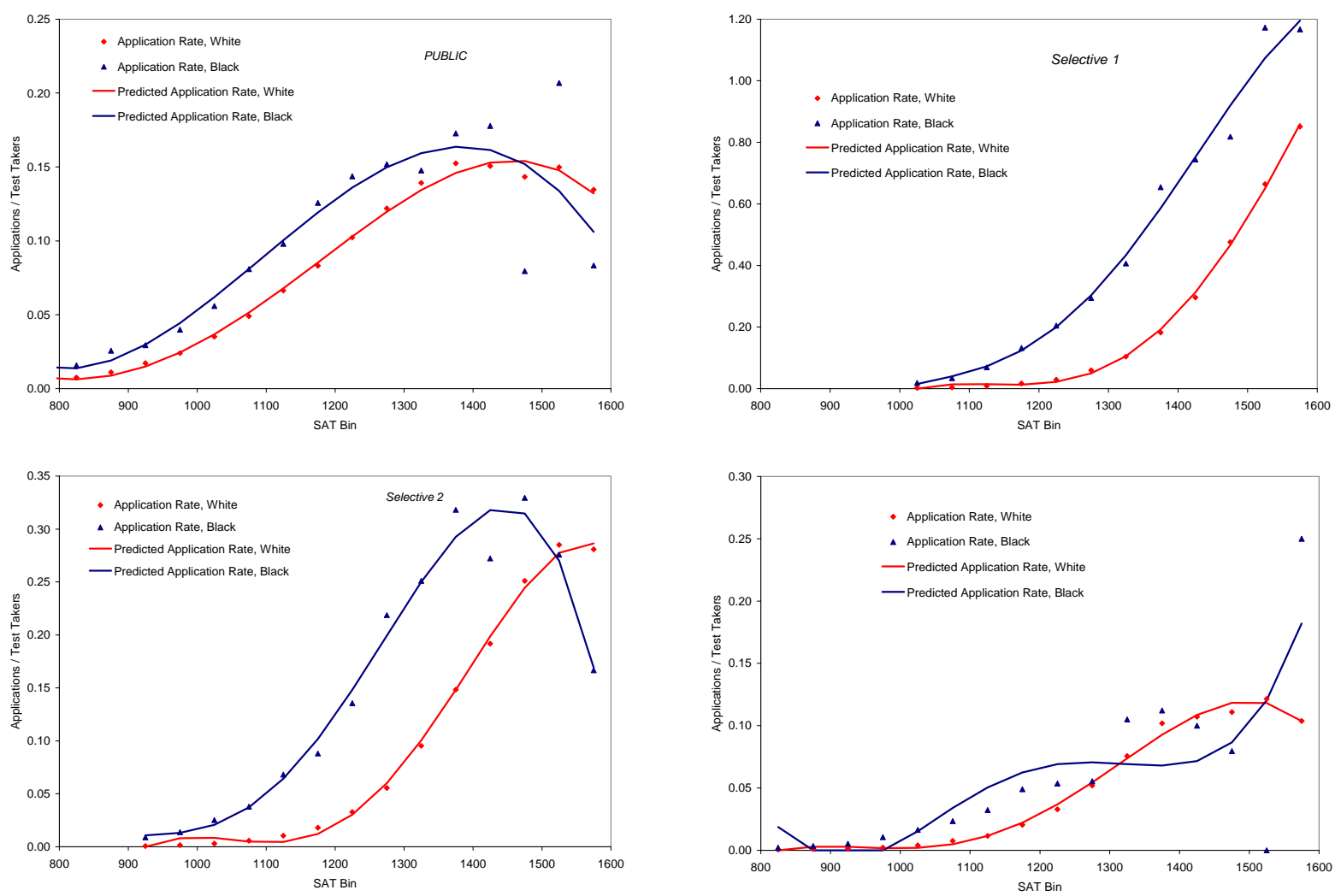

Source: Authors' calculations from Expanded College and Beyond. 
Table 1: Expected share of black students relative to white students, alternative income and test score distributions, maintaining current black application patterns

\begin{tabular}{|c|c|c|c|c|c|c|c|c|}
\hline & \multicolumn{2}{|c|}{ Public (P) } & \multicolumn{2}{|c|}{$\begin{array}{c}\text { Most } \\
\text { Selective (S1) }\end{array}$} & \multicolumn{2}{|c|}{$\begin{array}{c}\text { Highly } \\
\text { Selective (S2) }\end{array}$} & \multicolumn{2}{|c|}{$\begin{array}{c}\text { Moderately } \\
\text { Selective (S3) }\end{array}$} \\
\hline & $\begin{array}{c}\mathrm{B} / \\
\mathrm{B}+\mathrm{W}\end{array}$ & $\begin{array}{l}\text { Sh of Gap } \\
\text { Closed }\end{array}$ & $\begin{array}{c}\mathrm{B} / \\
\mathrm{B}+\mathrm{W}\end{array}$ & $\begin{array}{l}\text { Sh of Gap } \\
\text { Closed }\end{array}$ & $\begin{array}{c}\mathrm{B} / \\
\mathrm{B}+\mathrm{W}\end{array}$ & $\begin{array}{l}\text { Sh of Gap } \\
\text { Closed }\end{array}$ & $\begin{array}{c}\mathrm{B} / \\
\mathrm{B}+\mathrm{W}\end{array}$ & $\begin{array}{l}\text { Sh of Gap } \\
\text { Closed }\end{array}$ \\
\hline \multicolumn{9}{|l|}{ Status quo admissions rates (with race preferences) } \\
\hline Observed income distribution & 0.118 & & 0.171 & & 0.142 & & 0.094 & \\
\hline \multicolumn{9}{|l|}{$\begin{array}{l}\text { Projected race neutral admissions (using current white admissions } \\
\text { rates) }\end{array}$} \\
\hline Observed income distribution & 0.053 & 0.000 & 0.051 & 0.000 & 0.060 & 0.000 & 0.051 & 0.000 \\
\hline Counterfactual income distribution for families with children & 0.064 & 0.169 & 0.069 & 0.153 & 0.078 & 0.214 & 0.062 & 0.254 \\
\hline Observed income distribution, NAEP progress & 0.075 & 0.336 & 0.089 & 0.316 & 0.094 & 0.410 & 0.072 & 0.504 \\
\hline Counterfactual income distribution, NAEP progress & 0.088 & 0.545 & 0.118 & 0.557 & 0.117 & 0.700 & 0.087 & 0.835 \\
\hline School quality convergence & 0.061 & 0.125 & 0.064 & 0.110 & 0.072 & 0.146 & 0.059 & 0.182 \\
\hline Counterfactual income distribution, school quality convergence & 0.073 & 0.308 & 0.086 & 0.293 & 0.092 & 0.386 & 0.071 & 0.463 \\
\hline
\end{tabular}


Table 2: Expected share of black students relative to white students, alternative income and test score distributions, assuming blacks adopt current white application patterns

\begin{tabular}{|c|c|c|c|c|c|c|c|c|}
\hline & \multicolumn{2}{|c|}{ Public (P) } & \multicolumn{2}{|c|}{$\begin{array}{c}\text { Most } \\
\text { Selective (S1) }\end{array}$} & \multicolumn{2}{|c|}{$\begin{array}{c}\text { Highly } \\
\text { Selective (S2) }\end{array}$} & \multicolumn{2}{|c|}{$\begin{array}{l}\text { Moderately } \\
\text { Selective (S3) }\end{array}$} \\
\hline & $\begin{array}{c}\mathrm{B} / \\
\mathrm{B}+\mathrm{W}\end{array}$ & $\begin{array}{l}\text { Sh. of Gap } \\
\text { Closed }\end{array}$ & $\begin{array}{c}\mathrm{B} / \\
\mathrm{B}+\mathrm{W}\end{array}$ & $\begin{array}{l}\text { Sh. of Gap } \\
\text { Closed }\end{array}$ & $\begin{array}{c}\mathrm{B} / \\
\mathrm{B}+\mathrm{W}\end{array}$ & $\begin{array}{l}\text { Sh. of Gap } \\
\text { Closed }\end{array}$ & $\begin{array}{c}\mathrm{B} / \\
\mathrm{B}+\mathrm{W} \\
\end{array}$ & $\begin{array}{l}\text { Sh. of Gap } \\
\text { Closed }\end{array}$ \\
\hline \multicolumn{9}{|l|}{ Status quo admissions rates (with race preferences) } \\
\hline Observed income distribution (current application rates) & 0.118 & & 0.171 & & 0.142 & & 0.094 & \\
\hline Observed income distribution (white application rates) & 0.083 & & 0.057 & & 0.048 & & 0.047 & \\
\hline \multicolumn{9}{|l|}{$\begin{array}{l}\text { Projected race neutral admissions (using current white admissions } \\
\text { rates) }\end{array}$} \\
\hline Observed income distribution & 0.038 & 0.000 & 0.016 & 0.000 & 0.021 & 0.000 & 0.028 & 0.000 \\
\hline Counterfactual income distribution for families with children & 0.047 & 0.112 & 0.023 & 0.046 & 0.029 & 0.067 & 0.037 & 0.132 \\
\hline Observed income distribution, NAEP progress & 0.056 & 0.222 & 0.033 & 0.106 & 0.038 & 0.137 & 0.045 & 0.255 \\
\hline Counterfactual income distribution, NAEP progress & 0.068 & 0.366 & 0.046 & 0.194 & 0.051 & 0.246 & 0.057 & 0.446 \\
\hline School quality convergence & 0.045 & 0.081 & 0.022 & 0.036 & 0.027 & 0.047 & 0.034 & 0.090 \\
\hline Counterfactual income distribution, school quality convergence & 0.055 & 0.205 & 0.031 & 0.095 & 0.037 & 0.128 & 0.044 & 0.242 \\
\hline
\end{tabular}

Note: Share of gap closed is computed relative to simulations using current race-specific application rates (row 1). 
Table 3: Projections of admission pool with income-based affirmative action

\begin{tabular}{|c|c|c|c|c|c|c|}
\hline & \multicolumn{2}{|c|}{ Baseline } & \multicolumn{2}{|c|}{$\begin{array}{c}\text { Income } \\
\text { Convergence }\end{array}$} & \multicolumn{2}{|c|}{$\begin{array}{l}\text { Inc. + Test Score } \\
\text { Convergence }\end{array}$} \\
\hline & \# of & & \# of & & \# of & \\
\hline & Admits & $\%$ Black & Admits & \% Black & Admits & $\%$ Black \\
\hline \multicolumn{7}{|l|}{ Selective 1} \\
\hline No preferences & 3,426 & $5.1 \%$ & 3,494 & $6.9 \%$ & 3,686 & $11.8 \%$ \\
\hline \multicolumn{7}{|c|}{ Income preferences $(<\$ 35 \mathrm{k})$} \\
\hline Additional Admits & 773 & $15.3 \%$ & 752 & $13.0 \%$ & 840 & $22.1 \%$ \\
\hline Total Admits & 4,199 & $7.0 \%$ & 4,246 & $8.0 \%$ & 4,526 & $13.7 \%$ \\
\hline \multicolumn{7}{|l|}{ Selective 2} \\
\hline No preferences & 5,266 & $6.0 \%$ & 5,366 & $7.8 \%$ & 5,609 & $11.7 \%$ \\
\hline \multicolumn{7}{|c|}{ Income preferences ( $<\$ 35 \mathrm{k})$} \\
\hline Additional Admits & 686 & $21.2 \%$ & 660 & $18.0 \%$ & 740 & $26.9 \%$ \\
\hline Total Admits & 5,952 & $7.7 \%$ & 6,026 & $8.9 \%$ & 6,349 & $13.5 \%$ \\
\hline \multicolumn{7}{|l|}{ Selective 3} \\
\hline No preferences & 5,764 & $5.1 \%$ & 5,831 & $6.2 \%$ & 5,991 & $8.7 \%$ \\
\hline \multicolumn{7}{|c|}{ Income preferences $(<\$ 35 \mathrm{k})$} \\
\hline Additional Admits & 438 & $20.9 \%$ & 421 & $17.7 \%$ & 462 & $25.0 \%$ \\
\hline Total Admits & 6,201 & $6.2 \%$ & 6,252 & $6.9 \%$ & 6,453 & $9.8 \%$ \\
\hline \multicolumn{7}{|l|}{ Public } \\
\hline No preferences & 14,817 & $5.3 \%$ & 14,992 & $6.4 \%$ & 15,395 & $8.8 \%$ \\
\hline \multicolumn{7}{|c|}{ Income preferences $(<\$ 35 \mathrm{k})$} \\
\hline Additional Admits & 2,091 & $20.5 \%$ & 2,009 & $17.2 \%$ & 2,149 & $22.6 \%$ \\
\hline Total Admits & 16,908 & $7.2 \%$ & 17,001 & $7.7 \%$ & 17,544 & $10.5 \%$ \\
\hline
\end{tabular}

Note: Simulations assume status quo application behavior. 